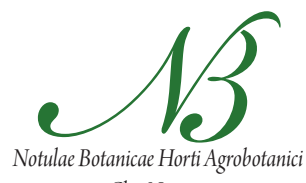

Cluj-Napoca

\title{
Effect of Different Growing Systems of Apple on Trunk and Branch Diseases and Pests
}

\author{
Maria BOROVINOVA', Vilina PETROVA', Svetla MANEVA² \\ ${ }^{1}$ Institute of Agriculture, Kyustendil, Bulgaria; mariaborovinova@abv.bg \\ ${ }^{2}$ Institute of plant soil agrotechnologies and plant protection "N. Poushkarov", Bulgaria
}

\begin{abstract}
The presented study aimed to determine apple's trunk and branch diseases and pests in three growing systems conventional, integrated and biological (organic). The investigations were made on an experimental apple orchard ( 1 ha) of the Institute of Agriculture at Kyustendil, Southwest Bulgaria in four consecutive years from 2007 to 2010. Three scab resistant cultivars 'Prima, 'Florina' and 'Erwin Baur' grafted on rootstocks MM106 were planted in 1996. The orchard was divided into four plots. One plot was treated conventionally with a normal pesticide programme, two plots were treated integrated according to the general principles, rules and standards of integrated apple production and one plot for biological (organic). The monitoring of pests and diseases and assessment of their density were done every two weeks. It was established that during the experimental period important disease and pests on apple trees in different growing systems were black rot Botryosphaeria obtusa, apple clearwig moth Synanthedon myopaeformis and shorthole borer Scolytus rugulosus. The damages by trunk and branch diseases and pests on apple were considerable higher in biological growing system. The mean rate of attack of cultivar 'Erwin Baur' by Botryosphaeria obtusa in biological and conventional growing systems was $52.35 \%$ and $4.65 \%$, respectively. The percentage of damaged by Scolytus rugulosus trunk and branch area per tree reach to 58.74 in biological and 0.23 in conventional system. Reduced vitality of apple trees growing with out pesticides and mineral fertilizers in biological growing system was the reason for strong infection of Botryosphaeria obtusa and attack of Synanthedon myopaeformis and Scolytus rugulosus.
\end{abstract}

Keywords: apple, Botryosphaeria obtusa, cankers, Scolytus rugulosus, Synanthedon myopaeformis

\section{Introduction}

The fungi Botryosphaeria obtusa, Nectria galligena, Leucostoma cincta, Schizophyllum alneum, Phomopsis spp. can infect trunks and branches of apples and cause lesions which enlarge into a cankers. B. obtusa can cause considerable loses especially in warm humid areas (Arauz and Sutton, 1989; Biggs and Miller, 2004). This pathogen causes cancers on trunks, branches, twigs and annual growths and black rot of fruits and can kills infected parts and entire trees(Brown-Rytlewski and McManus, 2000; Copes and Hendrix, 2004; Krishna et al., 2010). Cancers developed on cut-wounded and cold, hail, insect-injured apple trunks and branches (Beisel et al., 1984; Borovinova, 2000; Brown-Rytlewski and McManus, 2000; Proffer, 1989).

In Kyustendil region, Bulgaria the most important trunk and branch disease in apple orchards is Botryosphaeria cancer caused by B. obtusa. The rate of infected trees of cultivar 'COOP 10 ' on M9 reach to $34.85 \%$. Most damages are found on trunks and large branches (Borovinova, 2006).

Some pests as apple clearwig moth Synanthedon myopaeformis Borkh, leopard moth Zeuzera pyrina (L.) and species of the Scolytidae family attack pome and stone fruit trees. Apple clearwig moth Synanthedon myopaeformis is distributed through out the apple-growing countries of
Europe, North America and Asia (Al-Antary et al., 2005; Al-Antary and Ateyyat, 2006; Erler, 2010; Fraser, 2007; Khanh et al., 1994). Apple clearwig moth is economically important in Bulgaria (Kutinkova et al., 2006).

According to Balázs et al. (1996) Synanthedon myopaeformis is one of the secondary pests of apple trees weakened by other factors but it has become a significant pest. Apple clearwig can be important pest in orchards with slowlygrowing rootstocks, with intensive crown formations, integrated and biological pest control (Khanh et al., 1994).

The shothole borers Scolytus rugulosus and Scolytus mali are a bark beetles that live between the bark and the surface of the wood and damage trunks and branches of pome and stone fruit trees (Doerr et al., 2008; Karaka et al., 2010; Pelov and Sredkov, 1989; Petrov, 2005; Tezcan and Gulpercin, 2008). These pests are secondary pests and attack weak trees suffering from diseases, pests, water or nutrient deficiencies but young, healthy trees may also be attacked if they are close to orchards with high density of beetles (Pelov and Sredkov, 1989).

\section{Material and methods}

The investigations were made on an experimental apple orchard (1 ha) of the Institute of Agriculture at Kyustendil, Southwest Bulgaria in four consecutive years from 
160

2007 to 2010. Three scab resistant cultivars 'Prima', 'Florina' and 'Erwin Baur' grafted on rootstocks MM106 were planted in 1996. The orchard was divided into four plots. One plot (T I) was treated conventionally with a normal pesticide programme, two plots (T II) were treated integrated according to the general principles, rules and standards of integrated apple production (Cross and Dickler, 1994; Dickler and Schaffermeyer, 1991; Pelov et al., 1996; Stancheva et al., 2008) and one plot (T IV) for biological (organic) production. The monitoring of pests and diseases and assessment of their density were done every two weeks. During the period of investigation fungicide treatments in conventional and integrate growing systems were done against powdery mildew and insecticide treatments against codling moth, apple sawfly, green apple aphid, San Jose scale and leafrollers.

Protective treatments were made with copper-based fungicides to protect trees against fire blight (Erwinia amylovora (Burrill) Winslow) in three plant growing systems. In biological(organic) growing system powdery mildew was controlled by sanitary pruning. For pests control only Madeks (granulosa virus) and Mineral oil were applied.

In autumn, 72 trees of 'Prima', 'Florina' and 'Erwin Bour' for conventional and integrated systems and 56 trees for biological system were examined for cankers caused by Botryoshaeria obtusa and other fungi. The fungal pathogens were identified by fruit body of fungi and spores according to reference book of plant diseases(Bobev, 2000). The same trees were examined for pest damages. The pests were identified by adults, larvaes and damages (Popov et al., 1958).

The percentage of canker area and area damaged by species of Scolytidae family was estimated according to the scale of Townsend and Heuberger (Kremer and Unterstenhofer, 1967).

Data were processed by analysis of variance using $\mathrm{F}$ for test quantity estimation and LSD value for evaluation the statistical significance of obtained differences between treatment means and control in different level $(p<0.05$;
0.01 or 0.001 ) depending on the dispersion with in the variants.

\section{Results and discussion}

Permanent disease on the three cultivars was powdery mildew (Podosphaera leucotricha (Ell. et Salmon) in all the three growing systems during the examined period. In conventional system it was controlled by minimum 5 and maximum 8 treatments with fungicides and in integrated systems by minimum 4 and maximum 5 treatments. In biological (organic) growing system powdery mildew was controlled only by 2-3 sanitary pruning during vegetation. Damages by fire blight (Erwinia amylovora (Burrill) Winslow were found out only during several years and it was controlled by preventive treatments with copper containing fungicides.

B. obtusa and Schizophyllum alneum were determined as cause of cankers on trunk and branches. For the first time B. obtusa was discovered in 2004 in experimental orchard. The symptoms of B. obtusa on trunks and branches in three growing systems were identical. The area around the place of infection formed cancer was brown - reddish coloured. The infected tissue was sunken and sharply separated from healthy tissue. Picnidia were produced on the cankered area. Some of cankers girdled the branches and a part of the branches above the cankers died.

It was found that wounds caused by cold injury or mechanical injury(by cutting or machines) were the sites of Botryosphaeria cancers initiation. Our data confirmed that $B$. obtusa is wound pathogen. According to Brown and Britton, 1986; Brown-Rytlewski and McManus, 2000 infection commonly occurs via pruning wounds and damaged tissue.

Damages on trunks and branches of cultivars were different in the three growing systems during the experimental period (Tab. 1). Rate of attack of cultivars ranged from $1.04 \%$ to $54.17 \%$ for the three cultivars-'Prima, 'Florina' and 'Erwin Bawr'. The strongest damages caused by

Tab. 1. Damages on trunks and branches of different apple cultivars by Botryospheria obtusa in 3 growing systems

\begin{tabular}{|c|c|c|c|c|c|c|}
\hline \multirow{2}{*}{ Cultivar } & \multirow{2}{*}{$\begin{array}{l}\text { Growing } \\
\text { system }\end{array}$} & \multicolumn{5}{|c|}{ Rate of attack (\%) } \\
\hline & & 2007 & 2008 & 2009 & 2010 & mean \\
\hline \multirow{3}{*}{ 'Prima' } & T I & $1.04 \mathrm{C}$ & $4.17 \mathrm{C}$ & $6.25 \mathrm{C}$ & $6.25 \mathrm{C}$ & $4.43 \mathrm{C}$ \\
\hline & T II & 1.04 ns C & $11.46++C$ & 11.46 ns C & 11.96 ns C & $8.98+C$ \\
\hline & T IV & $26.56++++++$ & $37.50++++++$ & $37.50++++++$ & $37.50++++++$ & $34.77++++++$ \\
\hline \multirow{3}{*}{ 'Florina' } & T I & $0.00 \mathrm{C}$ & $1.92 \mathrm{C}$ & $3.85 \mathrm{C}$ & $3.85 \mathrm{C}$ & $2.41 \mathrm{C}$ \\
\hline & T II & $3.64 \mathrm{~ns} C$ & $2.88 \mathrm{~ns} \mathrm{C}$ & $2.88 \mathrm{~ns} \mathrm{C}$ & $2.88 \mathrm{~ns} \mathrm{C}$ & $3.07 \mathrm{~ns} C$ \\
\hline & T IV & $14.06+++$ & $17.19++++++$ & $15.63++++$ & $15.63++++$ & $15.63++++++$ \\
\hline \multirow{6}{*}{$\begin{array}{l}\text { 'Erwin } \\
\text { Baur' }\end{array}$} & T I & $1.56 \mathrm{C}$ & $3.40 \mathrm{C}$ & $6.82 \mathrm{C}$ & $6.82 \mathrm{C}$ & $4.65 \mathrm{C}$ \\
\hline & T II & $2.60 \mathrm{~ns} C$ & $14.77+++C$ & $15.48+C$ & $15.48+C$ & $12.08+++C$ \\
\hline & T IV & $54.16++++++$ & $54.17++++++$ & $46.88++++++$ & $54.17++++++$ & $52.35++++++$ \\
\hline & $\mathrm{F}$ & 40.87 & 90.78 & 35.53 & 39.51 & 167.54 \\
\hline & $\mathrm{Sd}$ & 4.02 & 2.68 & 3.69 & 3.90 & 1.88 \\
\hline & $\mathrm{LSD}_{0.05}$ & 8.10 & 5.44 & 7.48 & 7.85 & 3.75 \\
\hline
\end{tabular}

$\mathrm{C}$ - respective control to which the comparison has been done 
B. obtusa were measured in biological growing system. In this system damages were significantly higher compared to conventional and integrated systems. Statistically significant differences between damages of trees in conventional, integrated and biological system at different levels $(p<0.05, p<0.01$ and $p<0.001)$ were established for the years of investigation $(2007,2008,2009$ and 2010) as well as the average of them (Tab. 1).

The high rate of attack of trees by B.obtusa in biological system was due to the fact that this plot was not sprayed with fungicides and insecticides. The second reason for high rate of attack by $B$. obtusa was reduced vitality of trees growing without mineral fertilizers. The growth of the trees in conventional and integrated systems was stronger than the growth of the trees in biological system.

The present results are similar with these of Trapman at al. (2008) who stated that fruit rot cause by Diplodia $\operatorname{seriata}(B$. obtusa) was observed only in organically managed orchards and they have not found $D$. seriata in orchards under integrated pest management (IPM) in Northern Germany.

Rate of attack of cultivars 'Prima', 'Florina' and 'Erwin Baur' was different (Tab. 1). The most susceptible regarding rate attack was 'Erwin Baur' in three growing systems, but damages were significantly higher in biological system compared to conventional and integrated systems.

Several trees ( $4.5 \%$ of 'Erwin Baur' in conventional system and $8.3 \%$ of 'Prima' in integrated system) were infected by two fungi - B. obtusa and Schizophyllum alneum. The percentage of infected trees by two fungi in biological system was higher -'Prima'-18.75\%, 'Florina' - 6.25\% and 'Erwin Baur' - 37.5\%. Schizophyllum alneum was present as secondary pathogen was found out after infection of $B$. obtusa.

During the examined period insecticides in conventional and integrated systems were applied against codling moth (Cydia (Laspeyresia) pomonella L.), apple sawfly (Hoplocampa testudinea Klug.), green apple aphid (Aphis pomi De Geer.), Dysaphys mali, San Jose scale (Diaspidiotus perniciosus Comst.), leaf miners as Cemiostoma scitella Zell. and some leafrollers. The results of examination for pest damages on trunks and branches revealed that apple clearwig moth Synanthedon myopaeformis Borkh, leopard moth Zeuzera pyrina (L.) and species of the Ipidae (Scolytidae) family attacked and damaged apple trees during the investigated period. The damages (holes with larvae tunnel under the bark) of apple clearwig moth was discovered for the first time in 2004 in the experimental orchard and every year the damages caused by this pest has increased. The attack on the trees was associated with entry sites around wounds of pruning, mechanical damage, cold and machines injury. The average number of holes of the apple clearwig moth per tree were the highest in biological system (from 10.69 at 'Florina' to 36.48 at 'Erwin Bawr' (Tab. 2). In the integrated system the average number of holes of apple clearwig moth per tree was also high(with exception of cultivar 'Florina'). The damages caused by $S$. myopaeformis were insignificant in conventional system. The average number of holes of apple clearwig moth per tree were 2.7 and 5.7 times less compared to the integrated and biological growing systems. The difference between density of clearwing adults trapped in sex-pheromone traps at IPM and conventional plant protection was found out by Balázs et al. (1996). According to Balázs et al. (1996). S. myopaeformis has become a significant pest and this can be attributed to changes in apple production technology.

Comparing the assessed cultivars-'Prima', 'Florina' and 'Erwin Bawr' in the three growing systems, 'Erwin Bawr' was the most susceptible to apple clearwig moth.

Two species of Scolytidae family - Scolytus rugulosus and Scolytus mali were identified attacking apple trees in three growing systems but Scolytus rugulosus caused main damages. This pests caused significant damages in biological growing system. Damaged area of trunks and branches reached to $58.74 \%$ at 'Erwin Bawr' and $42.81 \%$ at 'Prima'. For the period of the investigation Scolytus rugulosus was an unimportant pest in both conventional and integrated systems. The percentage of damaged area per tree was very low from 0.23 to 6.81 (Tab. 2). Susceptibility of 'Prima', 'Florina' and 'Erwin Bawr' to Scolytus rugulosus were different. The most susceptible was 'Erwin Bawr'.

The high density and significant damages of trees in biological system was due to the fact that this plot was not sprayed with fungicides and insecticides and was growing without mineral fertilizers. The trees were weakened. The present data confirm the results of Pelov and Sredkov

Tab. 2. The average number and damaged area (\%) per tree by pest

\begin{tabular}{|c|c|c|c|c|}
\hline \multirow{2}{*}{ Growing system } & \multirow{2}{*}{ Cultivar } & \multicolumn{2}{|c|}{ Average number per tree } & \multirow{2}{*}{$\begin{array}{l}\text { Damaged area per } \\
\text { tree by } S . \text { rugulosus }\end{array}$} \\
\hline & & S. myopaeformis & Z. pyrina & \\
\hline \multirow{3}{*}{$\mathrm{TI}$} & 'Prima' & 8.04 & 0.17 & 1.04 \\
\hline & 'Florina' & 2.04 & 0.00 & 0.00 \\
\hline & 'Ervin Bawr' & 2.95 & 0.00 & 0.23 \\
\hline \multirow{3}{*}{ TII } & 'Prima' & 16.48 & 0.34 & 2.39 \\
\hline & 'Florina' & 4.50 & 0.04 & 1.23 \\
\hline & 'Ervin Bawr' & 14.43 & 0.00 & 6.81 \\
\hline \multirow{3}{*}{ TIV } & 'Prima' & 27.40 & 0.31 & 42.81 \\
\hline & 'Florina' & 10.69 & 0.00 & 12.88 \\
\hline & 'Ervin Bawr' & 36.48 & 0.22 & 58.74 \\
\hline
\end{tabular}


162

(1989) that borer species have a preference for trees weakened by other factors.

During period of investigation the density and damages caused by leopard moth Zeuzera pyrina (L.) were unimportant in three growing systems and the average number of $Z$. pyrina per tree was from 0 to 0.34 (Tab. 2).

\section{Conclusions}

The important trunk and branch disease and pests on apple trees in different growing systems during the experimental period were black rot Botryosphaeria obtusa, apple clearwig moth Synanthedon myopaeformis and shorthole borer Scolytus rugulosus.

The damages by trunk and branch disease and pests on apple trees were considerably higher in biological growing system. Reduced vitality of apple trees growing without pesticides and mineral fertilizers in biological growing system was the reason for the strong infection of Botryosphaeria obtusa and the attack of Synanthedon myopaeformis and Scolytus rugulosus.

\section{References}

Al-Antary T, Ateyyat M, Al-Rafae'a A (2005). Clearwing Borer in apple orchards in Ash-Shoubak. Al Mohandes Al-Ziraie 79:19-22.

Al-Antary T, Ateyyat M (2006). Flight activity and population trends of the small red-belted clear wing borer, Synanthedon myopaeformis (Borkh.) (Lepidoptera: Sesiidae), in apple orchards in Jordan. Jordan J Agric Sci 2(3):257-263.

Arauz LF, Sutton TB (1989). Temperature and wetness duration requirements for apple infection by Botryosphaeria obtusa. Phytopathology 79:440-444.

Balazs K, Bujaki G, Farkas K (1996). Incorporation of Apple Clearwing (Synanthedon myopaeformis Bork.) Control into the IPM System of Apple. Acta Hort 422:134-139.

Beisel M, Hendrix FFJr, Starkey TE (1984). Natural inoculation of apple buds by Botryosphaeria obtusa. Phytopathology 74:335-338.

Biggs A, Miller SS (2004). Rlative susceptibility of selected apple cultivars to fruit rot caused by Botryosphaeria. HortScience 39(2):303-306.

Bobev S (2000). Reference book of plant diseases in Bulgarian, $255 \mathrm{p}$.

Borovinova M (2000). Black rot of apple Botryosphaeria obtusa (Schwein) Shoem. Plant Science 37:50-55.

Borovinova M (2006). Susceptibility of apple cultivars to Botryosphaeria obtusa. Not Bot Horti Agrobo 34:100-105.

Brown-Rytlewski DE, McManus PS (2000). Virulence of Botryosphaeria dothidea and Botryosphaeria obtusa on apple and management of stem cankers with fungicides. Plant Dis 84:1031-1037.

Copes WE, Hendrrix FFJr (2004). Effect of temperature on sporulation of Botryosphaeria dothidea, B. obtusa, and $B$. rhodina. Plant Dis 88:292-296.
Doerr DM, Bruner JF, Smith ST (2008). Biology and management of bark beetles(Coleoptera: Curculionidae) in Washington cherry orchards. J. Entomol Soc. Brit Columbia 105:69-81.

Dickler E, Schaffermeyer S (1991). General principles, guidelines and standards for integrated production of pome 4 fruits in Europe. IOBC/WPRS Bulletin 24(3):1-66.

Erler F (2010). Efficacy of tree trunk coating materials in the control of the apple clearwing, Synanthedon myopaeformis. J Insect Sci 10:63-64.

Karaca G, Karaca İ, Yardimcı N, Demirözer O, Aslan B, Kılıç HÇ (2010). Investigations on Pests, Diseases and Present Early Warning System of Apple Orchards in Isparta, Turkey. African J of Biotech 9(6):834-841.

Khanh D, Balazs K, Meszaros Z (1994). Experiments to control the apple clearwing, Synanthedon myopaeformis Borkh. Novenyvedelem 30(5):219-224.

Kutinkova H, Andreev R, Subchev M, Szőcs G, Toth M (2006). Seasonal flight dynamics of the apple clearwing moth (Synanthedon myopaeformis BORKH., Lepidoptera: Sesiidae) based on catches in pheromone traps. Journal of Fruit and Ornamental Plant Research (Skierniewice, Poland) 14 (Suppl. 3):40-48.

Kremer Fr, Unterstenhofer G (1967). De l' emploi de la metode de Townsend et Heuberger dans l'interpretation de results d'essais phytosanitares. Pflanzenschutz Nachrichten, Bayer 4:625-628.

Krishna H, Biswajit Das, Brij Lal Attri, Minakshi Grover, Nazeer Ahmed (2010). Suppression of Botryosphaeria canker of apple by arbuscular mycorrhizal fungi. Crop Protection 29(9):1049-1054.

Pelov V, Sredkov I (1989). Species composition and role of parasites in Scolytus rugulosus (Col: Ipidae). 60 Years of Fruit-Growing institute, Kyustendil 242-253 p.

Petrov VA (2005). Fauna of the bark beetles(Coleoptera: Scolytidae) of Daghestan. Russian Entomol J 14(3):217222.

Popov V, Grigorov St, Makarov M, Burov D (1958). Determinant of noxious insects, 415 p. (in Bulgarian).

Proffer TJ (1989). Botryosphaeria Cankers and Dieback. Plant Patology Circular, November 1989:325.

Stancheva I, Borovinova M, Andreev R, Kalinova Sht, Balevski N, Simova S, Velcheva N, Staneva E, Draganova S, Arnaudov V, Kolev K, Stoev A, Rankova Z, Georgieva M (2008). Guidance for integrated plant protection of fruit trees. Ministry of Agriculture and Food, NSRZ, Bulgaria, book 3, $152 \mathrm{p}$.

Tezcan S, Gulpercin N (2008). A general evaluation of the fauna of cherry orchards in Turkey. Acta Hort 795:959-964.

Trapman M, Maxin P, Weber RWS (2008). Diplodia seriata, cause of black fruit rot in organically grown apples in Holland, Belgium and Northern Germany, Archived at http://orgprints.org/13668. 